\title{
Análisis de la instrucción de 1566 dictada por Felipe II para la conservación y restauración de las obras depositadas en el Monasterio "de Prestado" de El Escorial
}

\author{
María Belén DíEZ-ORDÁs BERCIANO \\ Escuela de Arte y Superior de Conservación y Restauración de León
}

RESUMEN. Este trabajo se centra en la identificación del espacio arquitectónico que aparece descrito como telón de fondo de las instrucciones dictadas por Felipe II, en las que se especifican las normas para la conservación y restauración de las pinturas de caballete que había depositado en El Escorial. La orden, fechada el 4 de julio de 1566, menciona piezas de la importancia del Descendimiento de Roger Van der Weyden, La Gloria y el Noli me tangere de Tiziano, y las tablas de Patinir, Paisaje con San Cristobal y Las tentaciones de San Antonio Abad. El objetivo es demostrar que el lugar exacto donde fueron ubicadas estas obras fue la iglesia del Monasterio "de Prestado" de la Villa de El Escorial, y no la Iglesia Vieja, como se ha interpretado hasta ahora.

Palabras clave: Orden de 4 de julio de 1566; Monasterio de San Lorenzo el Real; Monasterio "de Prestado"; El Descendimiento de Roger Van der Weyden; La Gloria de Tiziano; Noli me tangere de Tiziano; San Cristobal de Patinir; Las Tentaciones de San Antonio de Patinir; Iglesia de Prestado.

Abstract. This paper is focused on the identification of architectural space that is described as background to the instructions issued by Philip II. In this Order the conservation and restoration regulations of the easel paintings, that had been sent to El Escorial, were laid down. Important works as The Deposition by Roger Van der Weyden, The Glory and Noli me tangere both by Titian, and two panels by Patinir, Landscape with Saint Christopher and The Temptations of San Antonio Abad, have been identified on the Order dated July 4th, 1566. The main objective is to demonstrate that these works were kept in the church of the Borrowed Monastery located in the village of El Escorial, and not in the Old Church as it has been believed so far.

Key words: Instruction of 4 July 1566; The Royal Monastery of San Lorenzo; Borrowed Monastery; The Deposition by Roger Van der Weyden; The Trinity in Glory, and Noli me tangere by Titian; Landscape with Saint Christopher by Patinir; The Temptations of Saint Anthony by Patinir; Borrowed Church.

El presente trabajo toma como punto de partida la orden redactada por Felipe II, en 1566, para la conservación y restauración de las pinturas que envía a El Escorial durante la construcción del monasterio ${ }^{1}$. El

\footnotetext{
${ }^{1}$ Texto transcrito en el apéndice documental. Pu-
} 
documento describe de forma imprecisa la ubicación de las obras remitidas. Esta falta de detalles, unida al hecho de que el contenido del documento no ha sido objeto de un análisis preciso, ha generado cierta confusión a la hora de interpretar el espacio arquitectónico al que se refiere.

El memorial $\mathrm{u}$ orden-decreto dictado por Felipe II, en 1566, ha sido publicado íntegramente en dos ocasiones. La primera, en 1907, por Narciso Sentenach y Cabañas que lo transcribe en su obra titulada $\mathrm{La}$ Pintura en Madrid; y, posteriormente, en 1930, por el padre agustino fray Julián Zarco Cuevas en Los Pintores Españoles en El Escorial. Ambos autores se limitan a transcribir el documento sin añadir ningún comentario, a excepción de una aclaración a pie de página del texto de Sentenach, indicando que se trata de un escrito "copiado de una nota de letra de Felipe II, que ocupa justas las cuatro páginas de un pliego de papel; en otro pliego que le sirve de cubierta se lee de letra de Pedro de Hoyo: = De mano de su Magd. En 4 de jullio 1566" 2 . Resulta curioso que el autor no anote la referencia del archivo donde se encuentra el texto original, lo que ha impedido la consulta directa del mismo a la hora de realizar este estudio. Para más confusión, el historiador inicia la introducción al documento datándolo en 1576, mientras que termina la transcripción del mismo con la fecha ya señalada de 4 de julio de $1566^{3}$. Hemos

blicado por N. SENTENACH Y CABAÑAS, La pintura en Madrid: desde sus orígenes hasta el siglo XIX, Madrid, Administración del Boletín de la Sociedad Española de Excursiones, 1907, pp. 41-42; y por R. P. Fr. J. ZARCO CUEvas, Pintores españoles en San Lorenzo el Real de El Escorial [1566-1613], Madrid, Instituto de Valencia de Don Juan, 1931, pp. 29-32.

${ }^{2}$ Nota en la publicación de 1907 de N. SENTENACH Y CABAÑAS, La Pintura en Madrid..., p. 42, transcrita en 1930 por R. P. Fr. J. ZARCo CueVAS, Pintores españoles..., p. 32.

${ }^{3}$ Transcribo literalmente el inicio del texto tal y tenido a bien considerar que dicha fecha es una posible errata de edición -aunque en la fe de erratas no figura ninguna advertencia relacionada con ella-. Apoyamos esta decisión en el dato aportado por Sentenach al afirmar que la nota autógrafa de Felipe II era una instrucción dada por el monarca a su secretario, Pedro de Hoyo. Consultando las cartas intercambiadas entre los priores y los secretarios del rey, publicadas por Miguel Modino de Lucas, comprobamos que la última epístola de un prior dirigida a Pedro de Hoyo está fechada en 1568, momento en que toma el relevo como secretario real Martín de Gaztelu, hecho que demuestra que, en 1576, Pedro de Hoyo no pudo ser el destinatario de dicha nota manuscrita ${ }^{4}$.

Una vez despejado el problema de la datación del documento se presenta una nueva incógnita con respecto a su contenido. Hasta la fecha se ha considerado que las recomendaciones dadas por el rey estaban destinadas a mejorar las condiciones de la Iglesia de Prestado o Iglesia Vieja del Monasterio de San Lorenzo el Real, cuya construcción había comenzado en 1562, en un lugar cercano a El Escorial. Un análisis detallado de las pautas dadas por el monarca, permite extraer datos sobre el aspecto ar-

como aparece publicado en el estudio de Sentenach: "Y para que se comprenda á cuánto llegaba su solícita previsión y amor á sus obras preferidas, nada más pertinente que transcribir la curiosa nota-decreto, que de su puño y letra puso en una instrucción á su secretario. Decía así: 1576. Felipe II al Secretario Hoyo.Escorial.- Pinturas.- Hoyo. 'Lo que habeis de dejar ordenado aqui en lo de las pinturas, es esto, y dejadlo por escrito al Prior.' [...]". Como puede comprobarse, la fecha de "1576" está añadida al principio del texto por el transcriptor, por lo que no pertenece al documento original.

${ }^{4} \mathrm{M}$. MOdINO DE LuCAS, Los priores en la construcción del monasterio de El Escorial, vol. I, Madrid, Patrimonio Nacional, 1985 , p. 280, en esta publicación la última carta destinada a Pedro de Hoyo está fechada el 28 de agosto de 1568, a partir de entonces el prior dirigirá sus misivas a Martín de Gaztelu. 
quitectónico del espacio en el que estaban dispuestas las pinturas. De esta forma, al relacionar los detalles del edificio que aparece descrito en la orden, con las fases constructivas del monasterio del Real Sitio, surgen nuevas interpretaciones.

En este sentido, nuestro artículo desea aportar luz sobre el tema y plantear una nueva hipótesis sustentada en datos documentales contrastados, que sirva para esclarecer este breve momento de la historia de las obras pictóricas de la colección real identificadas en la orden de 1566. Las conclusiones obtenidas demostrarán que el Descendimiento de Roger Van der Weyden, La Gloria y el Noli me tangere de Tiziano, y las tablas de Patinir, Paisaje con San Cristobal y Las tentaciones de San Antonio Abad, fueron depositadas temporalmente en el Monasterio "de Prestado" que ocuparon los jerónimos en la Villa de El Escorial, mientras se edificaba el monasterio definitivo. Las obras permanecieron allí hasta una fecha indeterminada, que podemos aproximar en torno a los primeros años de la década de los setenta hasta 1574, en que aparecen inventariadas en las actas de la primera entrega, donde se documentan los bienes que Felipe II había donado a la congregación desde el inicio de la fundación, hasta el momento 5 .

Esta nueva interpretación sobre su ubicación cambia la redacción de numerosos textos que tratan sobre la historia de las obras mencionadas, a la vez que enriquece la idea que se ha tenido hasta ahora de la función que cumplió el Monasterio "de

\footnotetext{
${ }^{5}$ Las actas de las entregas han sido publicadas por R. P. Fr. J. ZARCo CUEvAS, Inventario de las alhajas, pinturas y objetos de valor y curiosidades donados por Felipe II al Monasterio de El Escorial (1571-1598), Madrid, 1930; y el proceso público ha sido analizado por J. M. DEL ESTAL, «Felipe II y su archivo hagiográfico de El Escorial», en Hispania Sacra, Vol. XXIII, Madrid, C.S.I.C., 1970, pp. 193-333.
}

Prestado" de la Villa durante la construcción del Monasterio de El Escorial'

\section{LA CONSTRUCCIÓN DE LOS MONAS- TERIOS DE EL ESCORIAL}

Para poder afrontar el análisis del espacio arquitectónico descrito en la orden de 1566, conviene conocer en profundidad el momento constructivo en el que se encontraban las iglesias de los dos posibles monasterios que pudieron albergar las pinturas enviadas por Felipe II. Esos dos edificios son: el Monasterio "de Prestado" de la Villa y el Monasterio de San Lorenzo el Real ${ }^{7}$.

\footnotetext{
${ }^{6}$ Antes de comenzar conviene establecer una terminología que evite los errores que pueda causar el hecho de que se utilizara el apodo de prestado para denominar tanto al monasterio e iglesia que los monjes utilizaban en la Villa, como para la iglesia del monasterio definitivo que hizo las veces de templo principal durante la construcción de la basílica. Por lo tanto, a partir de ahora, al Monasterio de San Lorenzo el Real también lo denominaremos utilizando expresiones como: monasterio de San Lorenzo de El Escorial, el monasterio definitivo o el monasterio del Real Sitio. Por el contrario, siempre que hagamos referencia al Monasterio "de Prestado" de la aldea, después Villa, de El Escorial nos referiremos a él como: Monasterio "de Prestado" -entrecomillando el apodo-, convento/monasterio de la aldea (hasta 1565) o convento/monasterio de la Villa (a partir del 8 de abril de 1565).
}

Así mismo, para las correspondientes iglesias de ambos edificios utilizaremos los siguiente términos: a la Iglesia de Prestado del monasterio del Real Sitio, que luego fue conocida como Iglesia Vieja, la llamaremos Iglesia de Prestado, sin entrecomillar; mientras que a la iglesia del convento de la aldea, la hemos bautizado como Iglesia "de Prestado", entrecomillando el apodo.

${ }^{7}$ La evolución arquitectónica de ambos edificios ya ha sido estudiada en profundidad. Remitimos a los siguientes trabajos publicados: A. BUSTAMANTE GARCÍA, «Los usos del Escorial con Felipe II», en El Legado de Borgoña. Fiesta y Ceremonia Cortesana en la Europa de los Austrias (1454-1648), edición a cargo de Krista De Jonge, Bernardo J. García García y Alicia Esteban Estríngana, Fundación Carlos de Amberes, Madrid, Marcial Pons Ediciones de Historia, 2010, pp. 91-108; 
La génesis constructiva de ambos edificios coincide en el tiempo. Una vez delimitada la zona donde se iba a erigir el nuevo monumento, el rey decidió enviar a un pequeño grupo de frailes encargados de la fundación de un convento bajo la advocación de San Lorenzo. Para su asentamiento se optó por la cercana aldea de El Escorial donde se alquiló primero, y después se compró una casa que, tras las rehabilitaciones necesarias, pasó a cumplir la función de convento provisional. Desde allí la comunidad se encargó de velar por la correcta organización y evolución de la fábrica ${ }^{8}$.

A. Bustamante García, J. ORTega Vidal, D. RodríGUEZ RUIZ, Las trazas de Juan de Herrera y sus seguidores, catálogo de exposición, Madrid, Patrimonio Nacional, 2001; J.L. CANO DE GaRdoQUI, La construcción del Monasterio de El Escorial, Valladolid, Secretariado de publicaciones de la Universidad de Valladolid, 1994; J.L. CANO DE GARDOQUI, «El Monasterio de Prestado de la Villa de El Escorial», en Boletín de la Real Academia de Bellas Artes de San Fernando, no 72, 1991, pp. 449-466; A. BUSTAMANTE GARCíA, «En torno a Juan de Herrera y la arquitectura», en Boletín del Seminario de Estudios de Arte y Arqueología, tomo 42, 1976, pp. 227-250; L. RU$\mathrm{BIO}$, «Cronología y topografía de la fundación y construcción del Monasterio de San Lorenzo el Real», en Monasterio de San Lorenzo el Real El Escorial. IV Centenario de la fundación (1563-1963), Biblioteca "La Ciudad de Dios", tomo X, Madrid, 1964, pp. 11-70; J. DONATE MARTíNEZ, «Fuentes para la historia del monasterio», en Monasterio de San Lorenzo el Real, El Escorial, IV Centenario de la Fundación (1563-1963), Biblioteca " La Ciudad de Dios", tomo X, Madrid, 1964; P. L. FERNÁNDEZ Y FERNÁNDEZ, «España en tiempos de Felipe II (1556-1598)», en Historia de España, tomo XIX, vol. II, dirigida por Ramón Menéndez Pidal, Madrid, EspasaCalpe, S.A., 1958; A. ROTONDO, Historia artística, pintoresca y descriptiva del Real Monasterio de San Lorenzo del Escorial, Madrid, 1862; E. LlagunO y AMIROLA, Noticias de los arquitectos y arquitectura de España desde su restauración, ilustradas y acrecentadas con notas, adiciones y documentos por D. Agustín Ceán Bermúdez, 5 vols., Madrid, 1829.

${ }^{8}$ Para la historia de la llegada de la comunidad a la aldea de El Escorial consultar: J.L. CANO DE GARDOQUI, «El Monasterio de Prestado....»; G. DE ANDRÉS MARTíNEZ, «Toponimia e historia de la montaña escurialense», en Anales del Instituto de Estudios Madrileños, tomo XI, p. 26: carta de Pedro de Hoyo a Felipe II, fechada el 3 de diciembre de 1561, donde el secretario
SITUACIÓN DE LA CONSTRUCCIÓN DEL MONASTERIO DEL REAL SITIO Y LA IGLESIA DE PRESTADO O IGLESIA VIEJA, EN 1566

A principio de 1566 se intentaba avanzar con fuerza en la fábrica. Los esfuerzos constructivos se centraban en el área del mediodía, donde se sitúa la zona monástica, ya que la comunidad esperaba ansiosa que se adecentasen esos espacios para poder trasladarse cuanto antes, con la esperanza de mejorar la falta de comodidad que estaban sufriendo en el Monasterio "de Prestado" $"$.

sugiere comprar o alquilar en la aldea de El Escorial, alguna casilla para la comunidad "aunque en cualquier casa que se compre o alquile se habrá de hacer algún gasto para ponerla al propósito de los que ellos habrán menester, salvo sino se comprase desde luego La Fresneda"; SIGÜENZA, «Libro tercero...», p. 441; M. MODINO DE LUCAS, Los priores..., vol. I, donde transcribe las siguientes cartas en las que se aborda el tema, en la p. 51 "Carta en A.G.P. Cédulas Reales, tomo II, fol. 168v. Monasterio de San Lorenzo", fechada el 27 de enero de 1562, donde Felipe II anuncia que la residencia de la comunidad será la aldea de El Escorial, y que allí vivirán durante las obras del monasterio; en la p. 52: “A.G.S., sección Casas y Sitios Reales, Obras y Bosques, Escorial, leg. 2, fol. 24", como respuesta, el 2 de febrero, el General de la Orden, fray Francisco de Pozuelo, devuelve una carta a Felipe II en la que comunica que avisará al recién nombrado prior para que esté dispuesto a ir a vivir a El Escorial con otro monje, cuando el rey lo mande; en la p. 57-58: "A.G.S., sec. C. y S.R., Obras y Bosques, Escorial, leg. 6", fechada el 2 de abril de 1562, en la que se ordena lo relacionado al aposento de la comunidad en la aldea, insistiendo en la necesidad de adquirir o mandar hacer una casa capaz de albergar a las personas encargadas de comenzar la empresa, en la que se harían tres altares.

${ }^{9}$ J.L. CANO DE GARDOQUI, «El Monasterio de Prestado...», p. 455 y nota 19 de la p. 462: A.G.S., sec. C. y S. R., leg. 258, fol. 296, "Holgaríamos mucho que habida resolución en lo de los claustros pequeños, Su Magd. fuese servido que el uno de ellos o siquiera un cuarto diésemos orden como se acabase con brevedad por la salud de los que aquí estamos, que cierto estamos tan estrechos que padecemos mucho calor en verano y frio en invierno, y la obra padece gran detrimento en no estar siempre todos en ella de día y de noche", documento fechado en julio de 1564. 
La documentación consultada hace referencia a las diferentes zonas del edificio en las que se estaba trabajando, describiendo el nivel que se había alcanzado en cada una de ellas. Pero centremos la atención en el sector más próximo a la Iglesia de Prestado o Iglesia Vieja.

En 1566, la iglesia estaba siendo construida entre los Claustros Chicos y el Patio Grande o de los Evangelistas. Mirando hacia el altar, situado al norte, lindaba al poniente con el Patio Menor o Segundo Claustro, y hacia el levante con el Patio de los Evangelistas (Fig. 1). A los pies de la iglesia, orientados hacia el sur, estaba previsto construir un aposento de prestado para Felipe II, del que haría uso hasta que se levantara la zona palaciega. La sacristía de la Iglesia de Prestado sería ubicada en el tránsito situado a la espalda del altar mayor, dejando una puerta de prestado a un lado del mismo ${ }^{10}$.

Por estas fechas, y con retraso sobre lo previsto, se envía a Madrid la tasación de la obra de los Claustros Menores ${ }^{11}$. Así

${ }^{10}$ A.G.S., sec. C. y S.R., Obras y Bosques, Escorial, leg. 6: "Lo que se acordó en El Escorial, a 25 de abril, sobre lo tocante a la obra del monasterio de San Lorenzo, glosado de mano de Su Majestad", fechado el 25 de abril de 1565, transcrito por M. MODINO DE LUCAS, Los priores..., vol. I, pp. 188-192, ver pp. 191-192: “La sacristía, de la iglesia de prestado, se ha de hacer en el transito que está a las espaldas del altar mayor de ella, y se ha de dejar una puerta de prestado a un lado del altar mayor para entrar de la sacristía a la capilla principal de la dicha iglesia de prestado. Al margen, el Rey. La sacristía estará aquí bien y lo de las puertas podrá quedar hasta mi vuelta, porque se vea bien dónde y cómo habrán de ser. Después de Julio se hizo memorial de cómo ha de ser esto".

11 Sobre la evolución de los claustros chicos: A. BUSTAMANTE, Las trazas de Juan de Herrera..., p. 117, comentarios a la traza de los claustros chicos de Juan Bautista de Toledo, fechada en 1565; A. BUSTAMANTE, «Los proyectos para el monasterio del Escorial», en $E l$ monasterio del Escorial y la arquitectura: actas del simposium, 8/11-IX-2002, coord. Francisco Javier Campos y Fernández de Sevilla, 2002, p. 54; M. MODINO DE LU- mismo, se estudian las condiciones para la construcción de las escaleras del refectorio y de la enfermería; y se trabaja en las bóvedas de las cantinas de levante y en la bóveda que está debajo del refectorio. Según cuenta el prior en una carta fechada el 19 de enero de 1566, a pesar de la nieve caída "se han puesto ocho o nueve ventanas con sus rejas y quedarán [...] acompañadas de tres o cuatro hiladas de mampostería, y la bóveda de debajo del refectorio [...] la acabarán esta semana". Con estos datos Felipe II deduce, en una nota al margen de la misiva, que "deben estar ya alzadas sus paredes a los XV pies". Además, según el prior, está cimbrado el suelo del coro de la capilla grande $\mathrm{y}$ "dáse todo prisa en ahondar los fundamentos de la cocina y de las necesarias"12.

La edificación de la iglesia era lenta. Prueba de ello es que, a mediados de 1568, se estaba discutiendo y poniendo las condiciones sobre el modo de hacer las armaduras de madera para los tejados, así como su tasación ${ }^{13}$. En 1570, entre los documentos

CAS, Los priores..., vol. I, p. 235, carta de fray Juan de Colmenar, prior, a Pedro de Hoyo, fechada el 19 de enero de 1566, en la que dice: “Cuando v.m. se partió de aquí [...] me dijo ciertas cosas [...] La una fué que se hiciese acá una tasa de los claustros y se enviase a Madrid. No la envío ahora porque Tolosa, a quién la encomendé, no la ha acabado".

12 Estos datos aparecen en una carta del prior fray Juan de Colmenar, dirigida a Pedro de Hoyo, con anotaciones de Felipe II: A.G.S., sec. C. y S.R., Obras y Bosques, Escorial, leg. 2, fol. 216, fechada el 19 de enero de 1566, transcrita por M. MODINO DE LUCAS, Los priores..., vol. I, pp. 235- 237.

13 “También se ha puesto en plática y dado las condiciones con que se han de hacer las armaduras de los tejados de la iglesia de prestado con algunos carpinteros para que las vean [...] y tenemos asímismo la tasación que Gaspar de Vega ha hecho de lo que merecerá esta obra": carta del prior y del contador a Pedro de Hoyo, fechada el 2 de mayo de 1568, A.G.S., sec. C. y S.R., Obras y Bosques, Escorial, leg. 1, publicada por M. MODINO DE LUCAS, Los priores..., vol. I, ver p. 275. En diciembre de 1568 se tiene noticia de que los pizarreros han "cubierto de pizarra la parte de la Iglesia de prestado hasta lo que toca el lienzo del claustro gran- 
conservados en el Archivo de la Biblioteca del Monasterio, se pueden localizar varias referencias sobre las intervenciones llevadas a cabo en la Iglesia de Prestado durante ese año, por ejemplo, en las nóminas de los canteros ocupados en labrar diferentes partes del edificio, aparecen mencionadas la "paredes de la iglesia de Prestado", o en el documento donde se definen las condiciones para enlosar su suelo ${ }^{14}$.

En resumen, en 1566 la Iglesia de Prestado o Iglesia Vieja del Real Sitio no tenía cubierta, el suelo del coro acababa de ser cimbrado, y aún faltarían años para que se finalizaran las paredes y el suelo. A la vista de estos datos resulta bastante improbable que Felipe II depositara en su interior las pinturas mencionadas en la orden del 4 de julio de 1566, por lo que sólo queda valorar la posibilidad de que las obras fueran instaladas en la capilla mayor del Monasterio "de Prestado" de la Villa de El Escorial (Figs. 2, 3 y 4).

de", ver CANO DE GARDOQUI, La Construcción..., p. 174 y nota 252 de la p.192: “C. y S.R. leg. 259 fol. 397 y $398^{\prime \prime}$.

${ }^{14}$ G. DE ANDRÉS, «Inventario de documentos sobre la construcción y ornato del Monasterio del Escorial existentes en el archivo de su Real Biblioteca», en Archivo español de arte, 45, 177, 1972, enero/marzo, p.18: “Caja I, año 1570, doc. 57. Nominas de canteros (67 hs.); doc. 61. Condiciones con que se ha de enlosar la iglesia de prestado (2 hs.)"; p. 19: “Caja I, año 1570, 71. Remate de ciertas piedras que se han de labrar y poner en la iglesia de Prestado ( 2 hs.)"; p. 21: "Caja I, año 1570, 116. Condiciones con que Antonio de Molina y Gaspar Rodríguez, maestros de rejerías, se han de obligar a hacer las rejas de la iglesia de Prestado (4 hs.)". CANO DE GARDOQUI, La Construcción..., p. 205 y nota 63 de la p. 236: “C. y S.R. leg. 258 fol. 85 y leg. 260 fol. 114"; y nota 64: "C. y S.R. leg. 260 fol. 123: para la navidad de 1570, se quiere que los rejeros de Valladolid tengan las rejas de la iglesia de prestado y estén asentadas, en 1571 se cobra la última cuenta".

\section{SITUACIÓN DEL MONASTERIO “DE PRESTADO" DE LA VILLA Y DE SU IGLESIA, EN 1566}

En 1564, se compró de forma definitiva la casa de El Escorial que habitaban los monjes. Durante estos años, el monarca se preocupó por tener a la comunidad asistida con los objetos que necesitaban, dada la precaria situación económica en la que se encontraban los monjes ${ }^{15}$. Desde que la casa de la aldea fue ocupada se había realizado en ella varias fases de reformas para mejorar su funcionalidad, acciones que incluían la mejora de la sala que hacía las veces de capilla mayor ${ }^{16}$. Dicho espacio contaba con un coro, -donde el prior quería poner un recaudo para que el rey siguiera los oficios-, para el que se estaba mirando cómo hacer las sillas, cuyo gasto correría a cuenta de la fábrica ${ }^{17}$.

\footnotetext{
${ }^{15}$ El secretario Pedro de Hoyo nos muestra cómo el monarca se preocupaba por paliar la mala situación de la comunidad: "Vuestra Majestad vea a cuya costa se han de proveer, porque, al presente, no tienen caudal los frailes, ni ducados para comprarlas ellos cuales serían menester". Carta del prior fray Juan de Huete dirigida a Pedro de Hoyo, fechada el 6 de diciembre de 1564, A.G.S., sec. C. y S.R., Obras y Bosques, Escorial, leg. 2, fol. 127-128 y anexo, transcrita por M. MODINO DE LUCAS, Los priores..., vol. I, p. 154.

${ }^{16}$ El 3 febrero de 1563, el General de la Orden de San Jerónimo se dirige al rey para recordarle que el prior y los monjes que ha mandado asentarse en El Escorial, necesitan "que haya en la Capilla que está en aquel aposento y Casa donde están, el Santísimo Sacramento porque recen allí las horas y digan sus misas", A.G.S., sec. C. y S.R., Obras y Bosques, Escorial, leg. 2, fol. 32, publicado en M. MODINO DE LUCAS, Los priores..., vol. I, p. 63. SIGÜENZA, «Libro tercero...», p. 446: "Hízose una capilla razonable, que servía de iglesia, y por estar en su compañía mandó el rey le hiciesen también allí un aposento". Para el estudio de las reformas realizadas en este edificio consultar el artículo de J.L. CANO DE GARDOQUI, «El Monasterio de Prestado...»

17 Datos mencionados en un memorial enviado por el prior al secretario real, iluminado por Felipe II con sus habituales notas al margen. El texto, fechado el 6 de diciembre de 1564, es uno de los más extensos y
} 
A finales de 1564, Felipe II estaba pendiente de asentar de forma correcta la capilla mayor del Monasterio "de Prestado" hasta tal punto, que se comprometió en adquirir un retablo adecuado para su al$\operatorname{tar}^{18}$. El documento que revela este dato no

representativos en relación a las condiciones de vida de la comunidad en el Monasterio "de Prestado" de la aldea. Esta carta se conserva en el A.G.S., sec. C. y S.R., Obras y Bosques, Escorial, leg. 2, folio 127-128 y anexo. Ha sido publicada por M. MODINO DE LUCAS, Los priores..., vol. I, pp. 152-159. Sobre el recaudo ver $\mathrm{p}$. 155: “También querría mucho que de lo que por allá estará echado a un rincón, tuviésemos aquí, desde luego, con qué poner a Su Majestad unas cortinas, que estamos muy corridos de hacerlas de un trapo viejo ahumado que pedimos prestado, que acaecerá muchas veces que Su Magestad de necesidad ha de ser muy continuo a visitar esta su casa y obra, que vengan gentes a negociar con Su Magestad, que sea cosa vergonzosa que le veamos tan así y no en la majestad que conviene, que si acá hubiéramos tenido con qué, ya hubiéramos comprado de qué hacerlas". En una nota al margen Felipe II comenta que enviará un recaudo, "aunque sea viejo, aunque allá donde le ponen me parece que estorba a los que vienen a oir misas". El 8 de enero de 1565, el prior responde al comentario del rey diciendo: "A lo que Su Majestad le parece que a donde le ponemos las cortinas no está buen lugar, porque embaraza mucho a los que vienen a misa, acá teníamos de ello, por no estar en lugar tan decente más yo tengo ya pensado cómo se puede remediar y en abonando el tiempo lo haré aparejar, que es cosa que se hará muy presto y a poca costa", en A.G.S., sec. C. y S.R., Obras y Bosques, Escorial, leg. 2, del folio 134 al 174, en M. MODINO DE LUCAS, Los priores..., vol. I, p. 161. El 23 de enero, vuelven a tratar el tema: "Holgara mucho que también vinieran las cortinas y satén para poner a Su Majestad, porque ya tenemos donde ponerlas, donde Su Majestad no embarace a los que vinieren a misa" y añade el rey en una nota al margen: "De esto no hay tanta necesidad y quiero yo verlas poner", en A.G.S., sec. C. y S.R., Obras y Bosques, Escorial, leg. 2, folio 142, publicado por M. MODINO DE LUCAS, Los priores..., vol. I, p. 167.

${ }^{18}$ En una carta del prior, Felipe II mediante una nota al margen dirigida a su secretario, dice: "[...] También le escribiréis [al prior] que, de aquí a que se hagan los claustros y haya convento, iré proveyéndole y enviándole ornamentos que de presente sean menester para él, pero no los más ricos, ni todos, porque éstos habrán menester más tiempo para hacerse, y también será mejor que sirvan para la iglesia principal y que por esta de ahora, [se refiere a la iglesia del Monasterio "de Prestado"] me queda también cuidado de menciona la advocación a la que pensaba dedicar dicho altar, pero es de suponer que el rey estuviera pensando en la figura de San Lorenzo. Esta hipótesis cobra fuerza si atendemos a los hechos paralelos que estaban teniendo lugar en Venecia. Se trata de los trámites iniciados en agosto de 1564, para encargar a Tiziano un Martirio de San Lorenzo ${ }^{19}$. Tras el intercambio de misivas

mirar el retablo que sería bien que tengan y proveerle que en el lo de las sillas de coro de prestado miren allá como habrán de ser y que como hubieren de ser sean a cuenta de la obra", en A.G.S., sec. C. y S.R., Obras y Bosques, Escorial, leg. 2, fol. 127-128, anexo, publicado por M. MODINO DE LUCAS, Los priores..., vol. I, p. 157. El documento está fechado el 6 de diciembre de 1564, en ese año la Iglesia Vieja aún era un proyecto, por esa razón consideramos, sin duda alguna, que se refiere a la capilla mayor del Monasterio "de Prestado" para la que está pendiente encargar un retablo y unas sillas para el coro. En el anexo a este memorial, escrito a mano por el propio monarca, el rey anota ciertos aspectos que parece haber olvidado señalar a su secretario, y dice: "Al Prior escribid juntamente a lo que anoche os escribí que vea los altares que podrá haber en la iglesia de prestado [la del Real Sitio], pues, tiene allá las trazas o en otras partes, a propósito de los treinta frailes que ha de haber, y que avise también de ello porque lo he de menester a propósito de los ornamentos", ibídem p. 158, transcripción del anexo. En resumen, basamos esta interpretación en dos aspectos, primero que si las sillas fueran para el monasterio definitivo no haría falta especificar que el gasto que supongan sea "a cuenta de la obra", y segundo, apoyándonos en el texto del anexo al memorial donde el monarca envía al prior que calcule sobre las trazas los altares que podría haber en la iglesia de prestado, de lo que se deduce que si no conocía el tamaño de los altares no podría estar pendiente de encargar un retablo, como explica en la carta que precede al anexo. Otro detalle que nos permite desarrollar esta teoría es que en la orden de 1566, se menciona un retablo en el altar de la capilla mayor del edificio que identificamos con el Convento "de Prestado", de forma que consideramos que puede ser éste el que Felipe II estaba pendiente de proveer en 1564. Existen otras interpretaciones respecto el retablo mencionado en la carta de 1564: A. BUSTAMANTE, «Las estatuas de bronce del Escorial. Datos para su historia (I)», en Anuario del Departamento de Historia y Teoría del Arte, vol. V, 1993, pp. 41-57, ver p. 42, considera que el retablo "es la primera referencia sobre este particular de la Iglesia Vieja que conocemos".

${ }^{19}$ C. GARCía-FríAs, Tiziano y el Martirio de San Lo- 
entre Madrid y Venecia, el monarca termina encargando la tela al maestro $y$, a uno de sus ayudantes, una copia de otra obra que Vecellio había pintado años antes con el mismo tema ${ }^{20}$. El cuadro fue entregado por Tiziano al embajador en Venecia el 3 de diciembre de 1567. Antes de que se recibiera la pintura en España, el 6 de enero de 1568 el rey mandó bendecir la capilla del Monasterio "de Prestado", donde ordenó colocar "para consuelo y alegría de los nuevos hijos de San Lorenzo el brazo de tan santo patrón"21. La pintura llegó a poder de

renzo de El Escorial: consideraciones histórico-artísticas tras su restauración, Madrid, Patrimonio Nacional, 2003, realiza un exhaustivo estudio sobre la obra. A. BUSTAMANTE, «Las estatuas...», p. 43, menciona este encargo y en la nota 11, aporta como referencia bibliográfica: "Tiziano e la Corte di Sapagna nei documenti dell'Archivio Generale di Simancas, p. 88 y ss. Madrid, 1975".

${ }^{20}$ C. GARCÍA-Frías, Tiziano .... Por el mes de octubre, el secretario del embajador responde que el encargo deberá de esperar ya que Tiziano se encontraba en Brescia, pero que podría conseguir una copia de un cuadro del maestro que representaba el martirio de dicho santo, realizada por mano de Girolamo Dente, ayudante del artista, en la mitad de tiempo en que Tiziano tardaría en pintar la obra. Sobre la estancia de Tiziano en Brescia cita una carta, fechada el 8 de octubre de 1564, en la p. 17 y en la nota 6 de la p. 46: "A.G.S., Estado, leg. 1.325, fol. 44 minuta, publicado por Crowe y Cavalcaselle, 1877, tomo II, p. 326". Sobre la oferta de realizar una copia de la obra que Tiziano había pintado para la desaparecida iglesia de los Crociferi de Venecia, cita una carta fechada el 9 de octubre de 1564 en la p. 17 y en la nota 8 de la p. 46: ““A.G.S., Estado, leg. 1.325, fol. 45, publicado por Crowe y Cavalcaselle, 1877, tomo II, p. 220-222". El 15 de octubre, Felipe II le hace saber que está interesado tanto en la copia de la versión veneciana como en que Tiziano realice una nueva versión del tema, aunque se ignora si llegó a realizarse la copia solicitada, p. 20 y nota 10 de la p. 46: “A.G.S., Estado, leg. 1.325, fol. 50-51, pub. por Cloucas, 1967, p. 268".

21 SIGÜENZA, «Libro tercero...», p. 452, y en SIGÜENZA, La fundación del monasterio de El Escorial, Madrid, Turner, 1986, p. 38. La reliquia aparece descrita en las actas de la primera entrega -en particular en la fechada en 1571-, publicadas por Zarco Cuevas, con el número 423: “Un braço del bienaventurado sanct Lorenço, que envió a su Magestad el Duque de Saboya, metido en otro braço de plata, como que está santi-
Felipe II en el verano de $1568^{22}$. ¿Por qué no suponer que la obra de Tiziano fue colocada en el retablo de la capilla del Monasterio "de Prestado"? Si demostramos que el rey trasladó a dicha capilla obras tan queridas por él, como La Gloria de Tiziano o El Descendimiento de Van der Weyden, no resultaría improbable que enviara esta pintura recién encargada, que trataba un tema tan adecuado para el lugar donde acababa de depositar una reliquia del nivel del brazo de San Lorenzo. En 1566, en la capilla mencionada en la orden que procederemos a analizar a continuación, había un retablo que quizá estaba a la espera de recibir una tela que representara un Martirio de San Lorenzo.

A finales de 1566, el convento seguía siendo objeto de diferentes reformas. Por estas fechas se tiene constancia de ciertos envíos de madera para las puertas y ventanas $^{23}$. Este dato será de gran importancia

guando; labrado todo a lo antiguo... I. y M. B. Iv. E. I⿳a., 4." (El folio 4 de la primera entrega corresponde a las fechas de 20, 23, 24 y 25 de noviembre de 1571), R. P. Fr. J. ZARCO CUEVAS, Inventario de las alhajas..., p. 73.

${ }^{22}$ Datos sobre el periplo del cuadro del Martirio de San Lorenzo de Tiziano, consultar el trabajo de C. GARCÍA-FRÍAS, Tiziano..., p. 21. La autora del completísimo estudio no ha encontrado datos sobre la ubicación de la obra desde que es recibida por Felipe II hasta que aparece en el acta fechada en 1574, correspondiente a la primera entrega, en la que se inventarían las pinturas donadas al monasterio de El Escorial. Es por este vacío documental por lo que se aventura a suponer que la pieza estuvo depositada en el Alcázar de Madrid entre 1568 y 1574. Pero esta última fecha no puede ser tomada como el momento de la llegada de la obra al monasterio ya que, como se verá más adelante, la documentación conservada demuestra que en 1570, el retablo junto a la tela de Tiziano, estaban siendo instalados y aderezados en la iglesia de prestado del Real Sitio.

23 J. L. CANO de GARdoQui, La Construcción..., p. 161: “Un año más tarde [finales de 1566] son destinadas grandes cantidades de madera de pino para la Fábrica originaria de los lugares mencionados, especialmente para las puertas y ventanas del Monasterio "de prestado" y de la propia Obra"; y nota 155 de la p. 
para demostrar nuestra hipótesis, como se podrá comprobar durante el análisis de la orden para la conservación de las pinturas, ya que el rey manda hacer ventanas para la capilla mayor mencionada en el documento.

En 1567, ante los retrasos que se estaban produciendo en la adjudicación de los destajos de los Claustros Chicos, se decidió acometer nuevas reformas en el convento de la Villa. Se hace una ampliación del edificio aumentando el número de celdas para mejorar las condiciones de los dieciséis monjes que ya estaban allí asentados; se realizan mejoras en otras estancias, como el refectorio y la cocina. En julio de 1567 , se acometen obras relacionadas con el aposento del rey de forma que las estancias del monarca, repartidas en dos alturas, estaban adosadas a la capilla mayor del convento, coincidiendo la altura superior con la zona del coro ${ }^{24}$.

\section{ASPECTO ARQUITECTÓNICO DEL CON- VENTO DESCRITO EN LA ORDEN DE 1566}

Las órdenes dictadas por Felipe II, en la instrucción del 4 de julio de 1566, están enfocadas hacia la conservación y restauración de las obras pictóricas que había enviando a El Escorial. La finalidad era que

190: “C.M.C. 1aép. leg. 931”.

24 J.L. CANO DE GARDOQUI, «El Monasterio de Prestado...», p. 455, nota 22 de la p. 426 ("DONATE MARTínEZ, J., «Fuentes para la historia del Monasterio», en Monasterio de San Lorenzo el Real, El Escorial, IV Centenario de la Fundación 1563-1963. Biblioteca “La Ciudad de Dios", tomo X, Madrid, 1964, p. 310), y documentos de las pp. 464 y 465 . El aposento de Felipe II tenía dos alturas y, en el piso superior, un balcón que daba a la plaza, ver p. 465, documento VI. Estas dos alturas corresponderían a la planta de la capilla y a la del coro, al que el rey salía a oír misa. Data de albañiles destajeros: A.G.S., sección de Contaduría Mayor de Cuentas, $1^{\mathrm{a}}$ ép. leg. 931, mencionado en la p. 456 y en la nota 28 de la p. 463. las pinturas estuvieran en perfectas condiciones y adecentadas con sus respectivos marcos cuando llegara la hora de su viaje definitivo al Real Sitio, como se deduce de las palabras del monarca, al decir: "Que todas las cajas en que vinieren estas tablas de Madrid se guarden, para que en ellas se suban en acabándose el Monasterio"25.

Felipe II demuestra ser un gran observador, que junto a su capacidad organizativa, le permite atender hasta el mínimo detalle que pudiera afectar de forma negativa a las obras. Sus conocimientos sobre los materiales que constituyen las piezas, le llevan a establecer ciertas normas para su correcta conservación, muy cercanas a los criterios actuales de conservación preventiva; aunque también ejecuta otras intervenciones que en nuestros días se consideran nefastas, como el encargo al Mudo de cortar el lienzo de Tiziano del Noli me tangere. Pero no debe extrañar dicha decisión ya que la consideración del arte en el siglo XVI era diferente, lo importante era conservar la imagen, algo que respetó al pie de la letra encargando una copia de la obra a Sánchez Coello ${ }^{26}$.

${ }^{25}$ Orden de 4 de julio de 1566, transcrita íntegramente en el apéndice documental. A partir de ahora, las frases entrecomilladas que aparecen en las notas a pie de página hacen referencia a este documento.

${ }^{26}$ (En cursiva el fragmento del texto que aporta los datos referidos) "Que el Noli me tangere, de Tiziano, que hoy vimos, le corte el mudo como le pareciere y le ponga en un marco pequeño y él le aderece". "Que el otro sacado de éste, se ponga en un marco, y cuelgue en la iglesia con los demás". Gracias a estos datos sabemos que la copia de Alonso Sánchez Coello, conservada en El Escorial [P.N. 10014705; Poleró, no 190], fue pintada antes de 1566, mide 190 x $190 \mathrm{~cm}$. Aparece en el inventario de la primera entrega, en el acta de 1574, Zarco no 978. Podemos considerar que el valor que se le daba al arte en el siglo XVI era similar al que describe Jonathan Brown en relación al siglo XVII (ver J. BROWN, Imágenes e ideas en la pintura española del siglo XVII, Madrid, 1988, pág. 137). Según el autor no se pretendía conservar la materia de la obra, como se 
Gracias a sus minuciosas observaciones se puede entrever la estructura del edificio, así como el diseño de la capilla mayor a la que se refiere en la orden (Fig. 6), de forma que es posible desentrañar la identidad del monasterio protagonista de estas actuaciones.

Las estancias que el monarca nombra en la orden son: la sacristía, las celdas y la capilla mayor a la que se denomina "iglesia" en un par de ocasiones.

La sacristía estaba situada en una planta inferior respecto a las celdas ${ }^{27}$. Esta sala fue utilizada como una especie de almacén. En ella se guardaban las pinturas que tenían el marco en buenas condiciones, cubiertas con telas para evitar la acumulación de polvo. También había un conjunto de obras pequeñas que Felipe II encarga subir a las celdas de los monjes para su adorno, ya que ese sería su uso una vez que se trasladaran al monasterio definitivo ${ }^{28}$.

La capilla mayor o iglesia debía de tener una altura considerable de forma que La Gloria de Tiziano, con casi tres metros y medio de alto, podía ser colgada a suficiente distancia del suelo como para evitar sal-

hace actualmente, sino que el fin era conservar el concepto de la temática en sí. La importancia de una obra residía en la idea no en la realización, por lo que el diseño de Tiziano era lo que daba valor a la imagen. (Para consultar el inventario de Poleró de las obras que pertenecen a Patrimonio Nacional, ver: V. POLERó Y TOLEDO, Catálogo de los cuadros del Real Monasterio de San Lorenzo, llamado del Escorial, en el que se comprenden los del Real Palacio, Casino del Príncipe y Capilla de la Fresneda, Madrid, 1857).

27 “Que unas Pinturillas pequeñas que están agora en la sacristía, las suban acá arriba y las tengan por las celdas ó como les pareciere [...]".

28 "Que se hagan luego marcos, como hoy se acordó, para todos los lienzos que no los tienen, que los que los tienen bien están en la sacristía cubiertos con unos lienzos [...]". "Que unas Pinturillas [...] las tengan por las celdas ó como les pareciere, para que después se suban arriba cuando pasen al monasterio para el mismo efecto". picaduras al limpiar el piso, siguiendo las órdenes dictadas por el rey encaminadas a evitar el daño que les causaría el contacto con el agua ${ }^{29}$.

Según los datos que aporta la orden, la capilla mayor contaba con dos accesos. La puerta de la sacristía estaba situada en el lateral derecho de la iglesia respecto a su entrada principal ${ }^{30}$. Lo escueto de las descripciones no permite definir con precisión la ubicación de dicha entrada principal; el único rasgo que aporta en relación a este acceso, es que su altura era menor de los dos metros veinte centímetros que medía el Descendimiento de Roger Van der Weyden, ya que el rey propone que se realice en dicha puerta las reformas que se estimen oportunas para poder meter la tabla en la capilla $^{31}$.

29 "Que se hagan luego marcos, [...] y hase de hacer y poner el primero el Juicio de Tiziano, [...] y como se fueren poniendo en los marcos se han de ir colgando por las paredes de los lados del cuerpo de la Iglesia, tan altos del suelo que cuando se barra y riegue no se salpiquen los lienzos, que les haría mucho daño." La obra de Tiziano mencionada es La Gloria, conservada en el Museo del Prado [P. 432] que mide $346 \times 240 \mathrm{~cm}$. Zarco Cuevas identificó el Juicio con La Gloria del Museo del Prado, en su estudio sobre las actas de la primera entrega: "1.002. Otro lienzo en que está pintado el Juycio, con los retratos del Emperador Carlos quinto que esté en gloria, y del Rey, nuestros Señores; de mano de Tiziano; que tiene treze pies de alto y diez de ancho. E. I’., 198. Prado, 432", R. P. Fr. J. ZARCO CUEVAS, Inventario de las alhajas..., p. 138.

30 "Que hecho esto se metan las tablas en la capilla mayor y se ponga la de San Antón, á la mano izquierda en entrando, en el lugar que le quedó señalado, junto á la de San Cristobal, y las otras se pongan al otro lado [a mano derecha] cabo la puerta de la sacristia."

31 "Que el Descendimiento de la Cruz, de Lobaina, que se trujo del Pardo, después que esté aderezado, se meta en la capilla mayor, dando para ello en la puerta la mejor orden que les pareciere, porque agora no cabe por ella [...]". El Descendimiento (MP. 2.825) mide 220,5 x 259,5 $\mathrm{cm}$. $(-1 \mathrm{~cm})$, datos obtenidos del informe técnico realizado por Carmen Garrido durante la intervención de restauración llevada a cabo sobre la obra entre 1992 y 1993. Para consultar la intervención realizada: T. DÁ- 
La tabla del Descendimiento fue enviada desde los Países Bajos en una fecha próxima a 1564. Según se cuenta, el bajel en el que viajaba sufrió un naufragio, lo que provocó que las tablas que componían el panel se abrieran por causa de la humedad a la que se vieron expuestas, daño que no fue mayor gracias al correcto embalaje con el que estaban provistas ${ }^{32}$. Este daño fue la causa de que se acometiera una intervención sobre su soporte dirigida a estabilizar las tablas para evitar la pérdida del estrato pictórico. La obra estuvo ubicada en el Palacio de El Pardo desde donde se trajo a El Escorial en torno a la fecha de la orden. Es probable que el encargado del cuidado de la pieza fuera el entallador y ensamblador Gilles Bullon, adscrito a las obras reales de Aranjuez y de El Pardo, desde comienzo de

VILA y C. GARRIDO, «Proceso de restauración del Descendimiento de la Cruz. Roger Van der Weyden. Museo del Prado no. cat. 2.825», en X Congreso de Conservación y Restauración de Bienes Culturales, 29 de septiembre al 2 de octubre de 1994, coord. Mª Carmen Pérez, Cuenca, 1994.

${ }^{32}$ La noticia la ofrece Mander en su obra publicada en 1604, consultar: K. VAN MANDER, Le Livre des Peintres, vol. I, Editado por H. Hymans, París, 1884-1885, p. 100-101, dato citado por P. SILVA MAROTO, «58. El Descendimiento», en Felipe II, un monarca y su época, un príncipe del Renacimiento, catálogo, Madrid, Sociedad Estatal para la conmemoración de los Centenarios de Felipe II y Carlos V y Museo del Prado, 1998, pp. 350353. Sobre la fecha del envío del cuadro a España: P. SILVA MAROTO, «58. El Descendimiento...», p. 352, donde recoge la teoría que identifica la tabla con la que aparece en el inventario de El Pardo de 1564. SÁNCHEZ CANTÓN, «El primer inventario del Palacio de El Pardo (1564)», en Archivo español de arte y arqueología, no 28, 1934, p. 69: “Capilla. Primeramente. Vn Retablo del descendimiento de la cruz hecho a pinzel", nota 1 del autor: "Copia del Van der Weyden del Escorial, hecha por Coxcie, hoy en el Prado, no 1.893 ”. Sánchez Cantón consideraba que la tabla del inventario era una copia de la de Van der Weyden, pero años después varios autores han demostrado que era la original del flamenco. Para las nuevas interpretaciones ver: J.K. STEP$\mathrm{PE}$, «Mécenaut espagnol et art flamand au XVI siècle», en Splendeurs d'Espagne et les villes belges, 1500-1700, vol. I, Bruselas, 1985, p. 271. la década de los sesenta ${ }^{33}$. Quizá se refiera a una posible intervención de soporte al decir "después que esté aderezado, se meta en la capilla mayor [...], metido en los mismos maderos y sus tornillos como agora está, porque no se vuelva á abrir más". El rey ordena que se coloque de forma temporal en el altar, arrimado al retablo, mientras que se observa la evolución del soporte durante los meses de verano, para comprobar que la actuación sobre el soporte había dado buen resultado antes de que el Mudo comenzara la reintegración de la pintura "pintando lo que está saltado [...] de las vestiduras y en el campo"34.

El altar de la capilla mayor estaría ligeramente alzado sobre una tarima para permitir que los monjes vieran los oficios desde el coro ${ }^{35}$. La orden no menciona qué aspecto tenía el retablo que lo presidía.

-

${ }^{33}$ En contra de la opinión de Zarco Cuevas, que identifica al "M. Giles" del documento, con Gil o Giles Brevost, nosotros nos inclinamos por identificarle con Gilles Bullon o Gilles de Bullon, ya que su presencia en el monasterio está documentada desde 1570, mientras que Gilles Brevost aparece por primera vez en el entorno de El Escorial, en 1578. Ver R. P. Fr. J. ZARCO CUEVAs, Pintores españoles..., p. 30, nota 1. Datos sobre Gilles Bullon y Gilles Brevost en CANO DE GARDOQUI, La construcción..., p. 372-373.

34 “Que el Descendimiento de la Cruz, de Lobaina, que se trujo del Pardo, después que esté aderezado, se meta en la capilla mayor, dando para ello en la puerta la mejor orden que les pareciere, porque agora no cabe por ella, y que se ponga sobre el altar arrimado al Retablo, metido en los mismos maderos y sus tornillos como agora está, porque no se vuelva á abrir más. Que pasado el verano y visto que no se vuelve á abrir le aderece el mudo, pintando lo que está saltado de los colores de las vestiduras y en el campo, mas no ha de tocar en el gesto ni tocado de Nuestra Señora, ni en otra cosa que no sea vestido ó campo como se lo señalé hoy".

${ }^{35}$ Sobre la arquitectura de los monasterios jerónimos ver J.A., RUIZ HERNANDO, «El Monasterio del Escorial y la arquitectura Jerónima» en El monasterio del Escorial y la Arquitectura: actas del simposium, 8/11-IX2002, coord. F. Javier Campos y Fernández de Sevilla, Madrid, Real Centro Universitario Escorial-María Cristina, 2002, p. 273. 
Según la descripción aportada por el documento, la capilla contaba con tres ventanillas: una de mayor tamaño, que estaba antes de que se llevara a cabo alguna de las reformas previas; y dos más pequeñas en una pared de nueva construcción, por lo que las ventanas no estaban todas en el mismo paño. Felipe II mandó cubrir estos vanos con maderas que pudieran abrirse $y$ cerrarse cuando fuera necesario. A finales de 1566, está documentada la llegada al Monasterio "de Prestado" de la madera destinada para tal fin ${ }^{36}$.

La capilla mayor es la sala donde Felipe II ordena ubicar las obras a las que se les fuera colocando un marco nuevo, así como las que hubieran recibido las intervenciones de restauración que indica. A Gilles le encomienda "encolar con nervios todas las juntas de las tablas sin que quede ninguna, porque con esto se aseguran de no abrirse más". Esta operación, conocida también como enervado, consistía en encolar "nervios de vaca", en vez de los habituales de cáñamo, en las juntas de las tablas por el lado del reverso, lo que ofrecía resistencia ante los movimientos de la madera ocasionados por los cambios de temperatura y humedad relativa del entorno ${ }^{37}$. Felipe

\footnotetext{
36 "Que porque no entre el sol por las tres ventanillas que están en la capilla mayor, la una mayor que estaba antes, y las dos pequeñas en la pared nueva, se cierren con unas ventanillas de madera,[...]". El rey ordenó hacer unas ventanas y a finales de 1566 aparece en la documentación la llegada de maderas para las ventanas y puertas del Monasterio “de Prestado" ver: CANO DE GARDOQUI, La construcción..., p. 161 y nota 155 de la p. 190: C.M.C. $1^{a}$ ép. leg. 931.

${ }^{37}$ Para más datos sobre este tipo de refuerzo consultar: R. BRUQUETAS GALÁN, Técnicas y materiales de la pintura española del Siglo de Oro, Madrid, Fundación de Apoyo a la Historio del Arte Hispánico, 2002, p 391. Los nervios de vaca eran los pelos de las crines o del rabo del animal, considero que esta interpretación es más posible que la aportada por Rocío al considerar que eran nervios de animal. Aunque, como bien indica la autora, los tratados de pintura resultan imprecisos y difíciles de interpretar.
}

II conocía la utilidad de este procedimiento, por lo que encarga a Gilles que lo ejecute en todas las obras sobre soporte de madera, incluido quizá en el reverso del Descendimiento ${ }^{38}$. También le encarga que, junto con el aparejador de carpintería, realice los marcos "para todos los lienzos que no los tienen [...] y han de ser estos marcos anchos [...] y como se fueren poniendo en los marcos se han de ir colgando por las paredes de los lados del cuerpo de la iglesia". Para las tablas encarga marcos de ranura, adaptados al contorno de la pieza, para evitar que los soportes se deformen al estar sin ellos ${ }^{39}$.

En la capilla se guardaban las obras cubiertas con sus respectivas telas que eran retiradas con motivo de alguna celebración especial, ya que recomienda que "las fiestas que se entra alli á decir misa se tenga cuenta con que no se arrimen á ellos" ${ }^{40}$.

\section{-}

${ }^{38}$ En las fotografías tomadas antes de la intervención de 1992, se puede apreciar que la capa protectora de pintura de minio aplicada por el reverso del soporte durante la ejecución de la obra, había sido raspada en la zona de las uniones de las tablas que conforman el panel. Quizá, durante alguna de las intervenciones no documentadas o en la realizada en 1941, se rasparan estas posibles enervaduras para sustituirlas por las cuarenta y dos colas de milano que presentaba en el momento del estudio técnico realizado en 1992. El informe de la intervención no especifica la causa de estos raspados, por lo que son meras suposiciones que surgen a partir de los datos aportados por el texto de la orden. Las fotografías del estado inicial del panel pueden consultarse con facilidad ya que han sido publicadas en: T. DÁvILA y C. GARRIDO, «Proceso de restauración...», ver la imagen 9, p. 236.

39 “Que de las que agora están colgadas [las tablas] aderece también M. Giles las que hoy le dige y á las que no tuvieren marcos se les pongan; como han de quedar después, para que entonces se dejen, y agora no se tuercen estando sin ellos".

40 "Que se hagan unos lienzos que se puedan quitar y poner, conque estén cubiertas todas estas pinturas, por el porvo". "[Las obras] se han de ir colgando por las paredes de los lados del cuerpo de la Iglesia, [...] y todos se cubran con sus lienzos, y estén allí muy bien guardados; y las fiestas que se entra alli á decir misa se tenga cuenta con que no se arrimen á ellos". 
La atención dedicada por Felipe II a la conservación de las obras, nos ha permitido extraer la descripción de la capilla donde estaban siendo colocadas. Con estos datos podemos proceder a sacar las conclusiones que confirman la teoría planteada de que la capilla mayor de la orden de 1566 es la iglesia del Monasterio "de Prestado" de la Villa y no la Iglesia de Prestado o Iglesia Vieja del Real Sitio.

CONCLUSIÓN SOBRE EL LUGAR EN EL QUE SE UBICAN LAS OBRAS PICTÓRICAS NOMBRADAS EN LA ORDEN DE 1566

La hipótesis inicial parece adquirir firmeza tras este estudio.

Las pruebas aportadas sobre el momento constructivo, dejan claro que la Iglesia de Prestado del monasterio del Real Sitio no es la sala mencionada en la orden. En 1566, la iglesia no estaba en condiciones de albergar las obras ya que se encontraba en plena construcción: el cimbrado del suelo del coro sería finalizado durante ese año y la cubierta aún era un proyecto que no se llevaría a cabo hasta finales de 1568. Por otro lado, la capilla mayor del Monasterio "de Prestado" de la Villa, a pesar de seguir recibiendo reformas, era un lugar suficientemente habilitado para ofrecer cobijo a las piezas enviadas.

Según la orden de 1566, Felipe II se preocupó por cubrir con maderas las tres ventanillas de la capilla ubicadas en dos de sus muros. De esa forma pretendía proteger las preciadas pinturas instaladas en su interior del sol y de la entrada de pájaros que pudieran dañarlas.

Estas tres ventanas han generado cierta confusión al ser erróneamente identificadas con las que presenta la actual Iglesia Vieja del monasterio. La Iglesia Vieja no gozó de la iluminación de dichas ventanas mientras que cumplió la función de iglesia principal, momento en el que era conocida como Iglesia de Prestado, apodo que mantuvo hasta que la basílica entró en uso y pasó a ser llamada Iglesia Vieja. Poco después de perder ese cometido, fue objeto de una reforma para adaptarla a su nuevo uso como capilla en la que se celebraban los oficios de entierro de los religiosos ${ }^{41}$. El padre Sigüenza describe el desmantelamiento de la Iglesia de Prestado del monasterio, que hasta el momento había estado "partida en capilla principal y cuerpo de iglesia y coro y debajo el aposento del rey". Tras la reforma se transformó en un solo cuerpo y se alargó hasta obtener la iluminación de la fachada meridional, donde se encontraban las tres ventanas del muro sur, que habían sido parte del aposento provisional del rey situado en ese extremo ${ }^{42}$. Gracias a estas puntualizaciones se puede demostrar que las tres ventanillas descritas en la orden de 1566, no se corresponden con las tres ventanas de la actual Iglesia Vieja del monasterio, por lo que es imposi-

${ }^{41}$ C. GARCÍA-FríAS, Tiziano..., p. 33. La construcción de la Basílica se prolongó hasta 1585, momento en que tendría lugar la reforma.

42 SIGÜENZA, «Libro tercero...», p. 574: "bajando el coro y sus sillas que estaba a los quince pies de alto al suelo, poniendo los dos órdenes de las sillas de cada coro continuados en cada banda, [...], y así quedó una pieza muy grande de ciento cinco pies en largo y treinta y cinco en ancho, muy alegre y solada de mármol blanco y pardo [...]". B. BASSEGODA I HuGÁs, El Escorial como museo. La decoración pictórica mueble en el monasterio de El Escorial desde Diego Velázquez hasta Fréderic Quilliet (1809), Barcelona, Editorial, Memoria Artium, 2002, p. 194, hace referencia a: A. BUSTAMANTE GARCÍA, La Octava Maravilla del mundo (Estudio histórico sobre El Escorial de Felipe II), Madrid, Alpuerto, 1994, p. 423. Remitimos al lector a: A. BUSTAMANTE GARCÍA, Las Trazas de Juan de Herrera..., p. 117, donde comenta la traza de los claustro chicos y dice: "En el lienzo de mediodía está establecido el número de ventanas, que parte de la decisión previa de asignar tres para la Torre de la Botica, Refectorio y habitación de Felipe II", la traza está fechada en 1565, por lo que las tres ventanas del primitivo aposento real ya estaban definidas. 
ble que la iglesia de la orden fuera la Iglesia de Prestado del Real Sitio.

El retablo del altar descrito en la capilla mayor de la orden, es otra pieza clave para poder defender esta teoría. Consideramos probable que sea el que Felipe II se comprometió a buscar en 1564 y que en 1566 se encontraba aún sin finalizar a la espera de recibir el cuadro de Tiziano dedicado al Martirio de San Lorenzo. Si esto fuera cierto no abría nada que impidiera que la tabla del Descendimiento pudiera ser colocada delante de un retablo en el que no había ninguna imagen que ocultar. No disponemos de documentos concretos sobre los que podamos basar estas suposiciones, en cambio, hay varios hechos que pueden apoyar la teoría de que el retablo estaba sin finalizar y de que el cuadro de San Lorenzo encargado a Tiziano, podría haber tenido como destino temporal este retablo inacabado.

Fijémonos en los procesos de ejecución de los retablos para defender que, en 1566, el retablo no estaba finalizado. Era práctica habitual que la aplicación de la policromía de los retablos tardara en llegar tras la primera fase de su ejecución protagonizada por los ensambladores que remataban su trabajo, dejando el retablo en madera vista, asentado y dispuesto en su lugar. Los retablos podían permanecer montados y sin policromar durante largas temporadas, e incluso años. El maestro que lo policromaba tenía a su cargo el desmontado $\mathrm{y}$ apeo de las piezas, que eran llevadas a un taller, bien propio o improvisado para tal empresa. Una vez que estaba policromado ${ }^{43}$ se asentaban en el lugar definitivo y comenzaba la operación de resanado, en la que perfeccionaban los posibles desperfec-

\section{-}

${ }^{43}$ Sobre las técnicas de los policromadores consultar R. BRUQUETAS GALÁN, Técnicas y materiales de la pintura..., p. 388. tos del traslado y del montaje.

El retablo que nos ocupa pudo presidir durante años el altar de la capilla mayor sin estar policromado, ya que no habría prisa por rematar un retablo cuya ubicación era provisional. Esto podría ser demostrado gracias a la documentación conservada de los pagos que, con fecha muy posterior, el 11 de julio de 1570, se efectúan a Juan de Til "porque doró y estofó a su costa de oficiales, oro plata y colores y los demás materiales, el Retablo de San Lorenzo que está en el altar de la Iglesia de enprestado"; y el 16 de agosto, Rodrigo Rodríguez recibió "3.740 [...] (maravedíes) por lo que se ocupó en aderezar el Retablo e Imagen de San Lorenzo que está en la Iglesia de enprestado del dicho Monasterio, [...]" ${ }^{44}$. Podemos suponer, por la forma como están redactados los pagos y relacionándolos con los procedimientos que seguían los policromadores, que el retablo pudo ser desmontado de la capilla mayor del Convento "de Prestado" donde se encontraba, para ser dorado durante los meses previos a julio del 70, en un taller indefinido; y que una vez policromado, fue trasladado y montado en la Iglesia de Prestado del Real Sitio, con el cuadro de Tiziano colocado en su caja (Fig. 5). Este proceso de montaje fue realizado por Ro-

\footnotetext{
44 A.G.S., sec. C.M.C., $1^{\underline{a}}$ época, leg. 1.126, en J.L. CANO DE GARDOQUI, «Noticias sobre Juan de Til y otros pintores y doradores de la fábrica del Monasterio del Escorial», en El Monasterio del Escorial y la pintura: Actas del Simposium, 1/5-IX-2001, coord. por Francisco Javier Campos y Fernández de Sevilla, 2001, p. 498. En el artículo de 2001, el autor afirma que en julio de 1570, Juan de Til y Rodrigo Rodríguez dedicábanse a dorar y estofar el retablo de San Lorenzo, "instalado en el altar mayor de la iglesia provisional del Monasterio". Pero en un estudio realizado en 1994 afirmaba que en el momento en que fue policromado estaba situado "en el Monasterio 'de prestado' de la villa de El Escorial", ver J.L. CANO DE GARDOQUI, La construcción..., nota 230, p. 393. Consideramos que se ajusta mejor a la documentación encontrada la interpretación expuesta en 2001.
} 
drigo Rodríguez, encargado de rematar las uniones y de instalar la obra del veneciano.

Los monjes se trasladaron de forma definitiva a los Claustros Chicos, en 1571. Está documentado que durante ese año se comienzan a subir las obras y los objetos que tenían en el Monasterio "de Prestado", por lo que la colocación del retablo recién policromado en la iglesia del Real Sitio, parece coincidir en fecha con la preparación del traslado de la comunidad ${ }^{45}$. Este retablo pictórico aparece descrito en las actas de la primera entrega correspondientes al año 1574, es decir, cuatro años después de ser instalado en la Iglesia de Prestado o Iglesia Vieja del monasterio del Real Sitio ${ }^{46}$. Es

${ }^{45}$ Las actas de entrega no representan el momento exacto de la llegada de las piezas al monasterio. En las cartas de los priores aparecen referencias al traslado previo de las alhajas que después aparecen en las actas de la primera entrega, por ejemplo: ver A.G.S., sec. C. y S.R., Obras y Bosques, Escorial, leg. 1, fol. 105: "El prior del monasterio de San Lorenzo el Real, 28 de enero de 1571", donde menciona un retablico de ébano y plata que es trasladado al monasterio y que después aparece en el acta de la primera entrega correspondiente a noviembre de 1571 . La carta ha sido transcrita por $\mathrm{M}$. MODINO DE LUCAS, Los priores..., vol. II, p. 29: "Lunes 22 del presente [enero de 1571] se subieron las reliquias al monasterio conforme a lo que de parte de su Majestad se me mandó. [...] Llegó todo muy sano, sin la menor quiebra del mundo. Pusiéronse en la alcoba de la celda que está contigua al dormitorio y por más seguridad, se echaron puertas y llave a la alcoba. Vuestra Majestad vea si es servido que se suban también los ornamentos ricos y las cosas de plata que no son tan necesarias acá abajo. También se subió el retablico de plata y ébano", el retablo mencionado puede ser identificado con el que aparece en el acta de la primera entrega, fol. 37-38, R. P. Fr. J. ZARCO CUEVAS, Inventario de las alhajas..., pp. 204-205, nº 1.588 .

${ }^{46}$ R. P. Fr. J. ZARCO CUEVAS, Inventario de las alhajas..., p. 137: “995. Un lienzo grande del Martiro de sant Lorenzo, de noche; de mano de Tiziano, con dos colunas, friso, cornija y arquitrabe pintado de oro y azul; que tiene de alto diez y seys pies y de ancho treze, que sirue de retablo en el altar mayor de la dicha Iglesia [de prestado del Real Sitio]. E. 1ª , 196. Poleró, 471”. El folio 196 de la primera entrega corresponde al 12-16 de abril de 1574. La obra se conserva en El Escorial [P.N. 10014834]. importante señalar que el inventario redactado en 1574, describe el cuadro del Martirio de San Lorenzo de Tiziano junto con la estructura del retablo, cosa que no ocurre con los retablos colaterales que lo acompañan actualmente en la decoración de la Iglesia Vieja ${ }^{47}$. La redacción de las actas de entrega obedece a una orden dada por el monarca para inventariar todas las obras que había donado a la congregación desde el inicio de la fundación ${ }^{48}$. Si el retablo del Martirio de San Lorenzo es el mismo que Felipe II estaba pendiente de proveer en 1564, es evidente que se consideraba el retablo junto con la tela como una sola pieza donada por el rey. En cambio las estructuras de los retablos

\footnotetext{
${ }^{47}$ Los lienzos de los retablos colaterales aparecen descritos en las actas de la primera entrega del 12 al 16 de abril de 1574, p. 196, de la siguiente forma: El Entierro, Zarco n⿳0 996 “Otro lienzo de la figura de Christo nuestro Señor, que le ponen en el sepulcro; de mano de Tiziano; que tiene seys pies de alto y nueue de ancho.", Museo del Prado [P. 436]. La Adoración de los Reyes, Zarco no 997 “Otro lienzo que está pintada, de mano de Tiziano, la Adoración de los Reyes; de seys pies de alto y nueue de ancho" [P.N. 1014835; Poleró, $\mathrm{n}^{\circ}$ 472]. Curiosamente en ninguno de los dos casos se describe el retablo mientras que sí lo hace en la entrega del retablo del Martirio de San Lorenzo, que aparece en la misma acta.

${ }^{48}$ La redacción de las actas de entrega fue ordenada por Felipe II el 9 de septiembre de 1571, fecha de la cédula por la que se encarga a Hernando de Bibriesca, guardajoyas real, que se traslade al monasterio para inventariar "los ornamentos, frontales, palios, paños de tapicería, alhombras, retablos, ymágenes, pinturas, quadros, libros de sacristia y oratorio, y las cruces, cálizes, custoridas y otras cosas, ansí de oro y plata, con piedras y sin ellas, como en otra manera que hauemos mandado hazer, y se han hecho por gasto $\mathrm{y}$ quenta de nuestro guardajoyas, cámara y thesorería; lo qual se ha ido dando y entregando y embiando al Monasterio de sant Lorenço el Real, que nos fundamos, para seruiçio de la yglesia y culto diuino, altares, coro y sacristía dél, y porque hauemos mandado que [de] todo lo suso dicho y cada cosa y parte dello juntamente con las reliquias que se han lleuado y están en el Monasterio se haga Inuentario en la forma que conuiene, y por él se entregue de nueuo al prior, diputados y conuento del dicho Monasterio [...]". Texto transcrito por R. P. Fr. J. ZARCO CUEVAS, Inventario de las alhajas..., p. 21-22.
} 
colaterales de la Iglesia Vieja no aparecen descritos en las entregas, nombrando solamente las obras de Tiziano que los adornan, por lo que sus entablamentos, probablemente, corrieron a cargo de los monjes, por esa razón eran considerados como parte de los bienes de la comunidad y no como una donación de Felipe II.

Por lo tanto, volviendo a la capilla mayor de la orden de 1566 , se podría determinar que en dicha fecha, el altar del Monasterio "de Prestado" lucía un sencillo retablo "con dos colunas, friso, cornija y arquitrabe" en proceso de construcción, realizado en madera vista, preparado para poder recibir un lienzo, ser dorado y policromado. Delante de este retablo se expuso de forma temporal el panel del Descendimiento, para vigilar la adaptación de su soporte a la intervención realizada por Gilles, para que una vez establizadas las tablas que lo componían, el Mudo pudiera aderezar la pintura.

La orden aporta un dato más que apoya nuestra hipótesis inicial. Felipe II indica "Que todas las cajas en que vinieren estas tablas de Madrid se guarden, para que en ellas se suban arriba en acabándose el Monasterio", de lo que se deduce que las obras se encontraban a la espera de sufrir un nuevo traslado que las llevara al monasterio definitivo.

Desde el principio considerábamos que si las obras mencionadas en la orden de 1566 podían ser identificadas entre las que aparecen descritas en las actas de la primera entrega ${ }^{49}$, apoyaría la teoría del uso del

\footnotetext{
${ }^{49}$ Las actas de la primera entrega comenzaron a elaborarse en 1571, y se dividen en tres momentos diferentes que abarcan hasta 1574. En las actas pertenecientes a los años de 1571 y 1572, se inventarían las alhajas y utensilios básicos para poder establecer el culto en el nuevo monasterio: los paños y tapices, las piezas de iluminación, retablitos y relicarios. Las obras pictóricas mueble se limitan al acta fechada en 1574 .
}

Monasterio "de Prestado" de la Villa como lugar de almacenaje de las pinturas antes de su traslado al monasterio definitivo.

Las obras nombradas en la orden de 1566 son:

Pinturillas pequeñas.

Tabla de Nuestra Señora con dos puertas escritas que llevó Vanderese.

$\checkmark$ Nuestra Señora de tapicería guarnecida en plata.

El Descendimiento de la Cruz, de Lovaina, que se trajo del Pardo.

Tabla de San Antón.

Tabla de San Cristobal.

El Juicio de Tiziano.

El Noli me tangere de Tiziano.

La copia del anterior.

Comenzaremos por la pieza descrita como una "Nuestra Señora de tabla, con dos puertas escritas que llevó Vanderese", ya que la serie de pinturillas pequeñas resulta imposible de identificar con las piezas nombradas en la primera entrega. Los escasos datos que aporta el texto sobre la tabla de Nuestra Señora, permite relacionarla con la descripción de dos de las obras inventariadas en $1574^{50}$. La primera obra que podemos reconocer sin duda alguna entre las de la primera entrega, es el Descendimiento

Para el estudio de las entregas consultar R. P. Fr. J. ZARCO CUEVAS, Inventario de las alhajas..., y el artículo de J. M. DEL ESTAL, «Felipe II y su archivo...», pp. 216221 y pp. 244-292.

${ }^{50}$ Zarco nำ 1.369 y nํo 1.392 , identificamos las obras de las entregas con los números que les adjudicó Zarco Cuevas en el estudio citado. Las descripciones completas de las entregas se han transcrito en el esquema que se aporta al final del trabajo, bajo el título Tabla comparativa de las obras de la Orden de 1566 que pueden ser identificadas en las actas de la primera Entrega. 
de Roger Van der Weyden ${ }^{51}$. La tabla de San Antón y la de San Cristobal, atribuidas a Patinir por Sentenach, también son descritas en las actas ${ }^{52}$. Así mismo, el Juicio de Tiziano aparece en la primera entrega, identificado por Zarco con La Gloria ${ }^{53}$. El Noli me tangere de Tiziano, que fue cortado por orden de Felipe II y mandado copiar, lo encontramos descrito junto a la copia mencionada, que en las actas se atribuye a Alonso Sánchez ${ }^{54}$.

El resultado fue el esperado. Todas las obras que hemos podido identificar en la orden pudieron ser relacionadas con las piezas de la primera entrega que aparecen en las actas fechadas entre el 12 y el 16 de abril de 1574, al igual que otros objetos que el prior estaba trasladando al nuevo monasterio en 1571.

El paso de la historia por el Monasterio "de Prestado" de la Villa nos ha arrebatado la antigua capilla que estamos estudiando. En 1576, una vez que los monjes estaban asentados en el monasterio del Real Sitio, el convento pasó a funcionar como hospital, lo que motivó el derribo de la antigua iglesia para levantar una más grande adaptada a las necesidades que requería la nueva función del edificio ${ }^{55}$.

${ }^{51}$ Zarco $\mathrm{n}^{\mathrm{o}}$ 1.027. Actualmente conservada en el Museo del Prado [P. 2.825].

52 San Antón, Zarco no ${ }^{-}$887, Museo del Prado [P. 1.615]. San Cristóbal, Zarco no 877, El Escorial [Patrimonio Nacional nº 10014400; Poleró no 359].

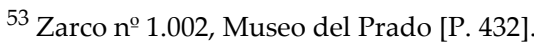

${ }^{54}$ El Noli me tangere de Tiziano, Zarco no 1.012 , Museo del Prado [P. 442]. La copia de Alonso Sánchez, Zarco $n^{-}$978, El Escorial [Patrimonio Nacional $n^{0}$ 10014705; Poleró no 190$]$.

55 “Primero día de setiembre de 1576 años, se pasaron los enfermos de la casa a do estaban en la villa del Escurial al monasterio viejo [...]. Pasados los enfermos, luego se bendixo la iglesia, porque la que tenían los frailes era pequeña y derribóse y hizose de nuevo la questá, que fue a 5 días de dicho mes de

\section{APÉNDICE DOCUMENTAL}

\section{Orden de 4 de julio de $1566^{56}$}

"Que unas Pinturillas pequeñas que están agora en la sacristía, las suban acá arriba y las tengan por las celdas ó como les pareciere, para que después se suban arriba cuando pasen al monasterio para el mismo efecto. Que una Nuestra Señora de tabla, con dos puertas escritas que llevó Vanderese, juntamente con la que está de tapicería guarnecida de plata, se lleve abajo y cuelgue en la pared donde pareciera, con las que agora están colgadas; digo la de tabla, que la de tapicería acá se la tendrán.

Que el Descendimiento de la Cruz, de Lobaina, que se trujo del Pardo, después que esté aderezado, se meta en la capilla mayor, dando para ello en la puerta la mejor orden que les pareciere, porque agora no cabe por ella, y que se ponga sobre el altar arrimado al Retablo, metido en los mismos maderos y sus tornillos como agora está, porque no se vuelva á abrir más. Que pasado el verano y visto que no se vuelve á abrir le aderece el mudo, pintando lo que está saltado de los colores de las vestiduras y en el campo, mas no ha de tocar en el gesto ni tocado de Nuestra Señora, ni en otra cosa que no sea vestido ó campo como se lo señalé hoy.

Que Giles acabe de encolar con nervios todas las juntas de las tablas sin que

setiembre [de] 1576", R. P. Fr. J. ZARCO CuEVAS, Documentos para la historia del monasterio de San Lorenzo del Escorial, I, Madrid, 1918, p. 49.

${ }^{56}$ Publicado por N. SENTENACH Y CABAÑAS, La pintura en Madrid: desde sus orígenes hasta el siglo XIX, Madrid, Administración del Boletín de la Sociedad Española de Excursiones, 1907, pp. 41-42, y por R. P. Fr. J. ZARCo CueVAS, Pintores españoles en San Lorenzo el Real de El Escorial [1566-1613], Madrid, Instituto de Valencia de Don Juan, 1931, pp. 29-32. Ambos autores no anotan la referencia del archivo donde se encuentra el texto original. 
quede ninguna, porque con esto se aseguran de no abrirse más.

Que hecho esto se metan las tablas en la capilla mayor y se ponga la de San Antón, á la mano izquierda en entrando, en el lugar que le quedó señalado, junto á la de San Cristobal, y las otras se pongan al otro lado cabo la puerta de la sacristia.

Que de las que agora están colgadas aderece también M. Giles las que hoy le dige y á las que no tuvieren marcos se les pongan; como han de quedar después, para que entonces se dejen, y agora no se tuercen estando sin ellos.

Que porque no entre el sol por las tres ventanillas que están en la capilla mayor, la una mayor que estaba antes, y las dos pequeñas en la pared nueva, se cierren con unas ventanillas de madera, que se puedan abrir cuando conviniere y cuando no estar cerradas, que también esto conviene, porque por allí no entren golondrinas y otros pájaros que dañen á las pinturas.

Que se hagan unos lienzos que se puedan quitar y poner, conque estén cubiertas todas estas pinturas, por el porvo.

Que todas las cajas en que vinieren estas tablas de Madrid se guarden, para que en ellas se suban arriba en acabándose el Monasterio.

Que se hagan luego marcos, como hoy se acordó, para todos los lienzos que no los tienen, que los que los tienen bien están en la sacristía cubiertos con unos lienzos; y han de ser estos marcos anchos como lo entendieron hoy Giles y el aparejador de la carpintería de aquí, y hase de hacer y poner el primero el Juicio de Tiziano, que hoy vimos, porque está muy mal tratado, y como se fueren poniendo en los marcos se han de ir colgando por las paredes de los lados del cuerpo de la Iglesia, tan altos del suelo que cuando se barra y riegue no se salpiquen los lienzos, que les haría mucho daño. Que los que estuvieren algo saltados los aderece el mudo, y todos se cubran con sus lienzos, y estén allí muy bien guardados; y las fiestas que se entra alli á decir misa se tenga cuenta con que no se arrimen á ellos.

Que el Noli me tangere, de Tiziano, que hoy vimos, le corte el mudo como le pareciere y le ponga en un marco pequeño y él le aderece.

Que el otro sacado de éste, se ponga en un marco, y cuelgue en la iglesia con los demás.

Todo esto se traslade para dejar aquí, y sise me olvida algo, añadidlo. -Hoyo."

Narciso SENTENACH Y CABAÑAS, $L a$ pintura en Madrid, Madrid, s.a., pp. 41-42. Dice en nota Sentenach: "Copiado de una nota de letra de Felipe II, que ocupa justas las cuatro páginas de un pliego de papel; en otro pliego que le sirve de cubierta se lee de letra de Pedro de Hoyo:= De mano de su Magd- En 4 de Jullio de 1566.- Diose copia al Pe Prior y al gd (Guardián?) rúbrica (la de Hoyo)." 


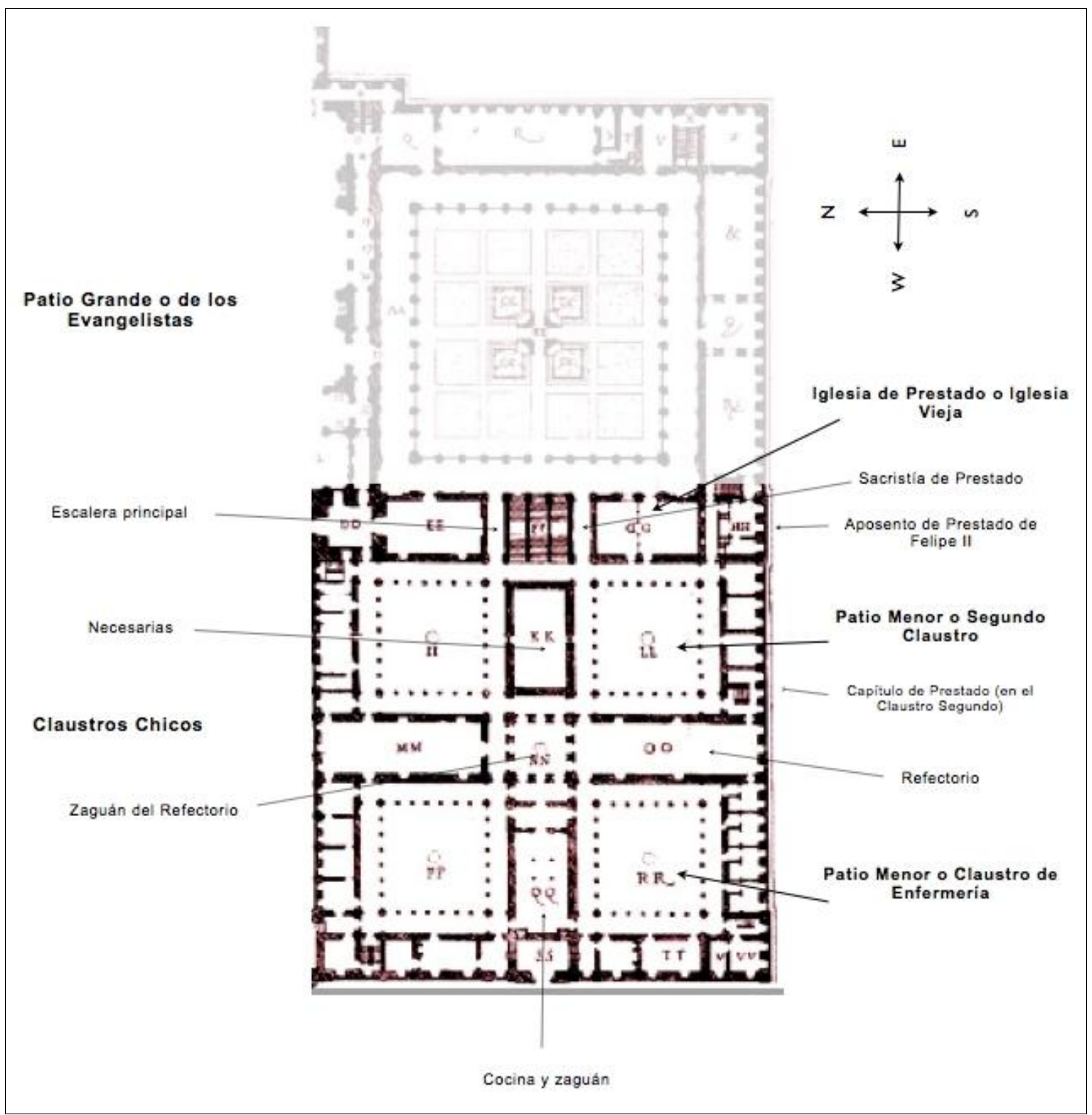

- Fig. 1. Ubicación de la Iglesia de Prestado. 


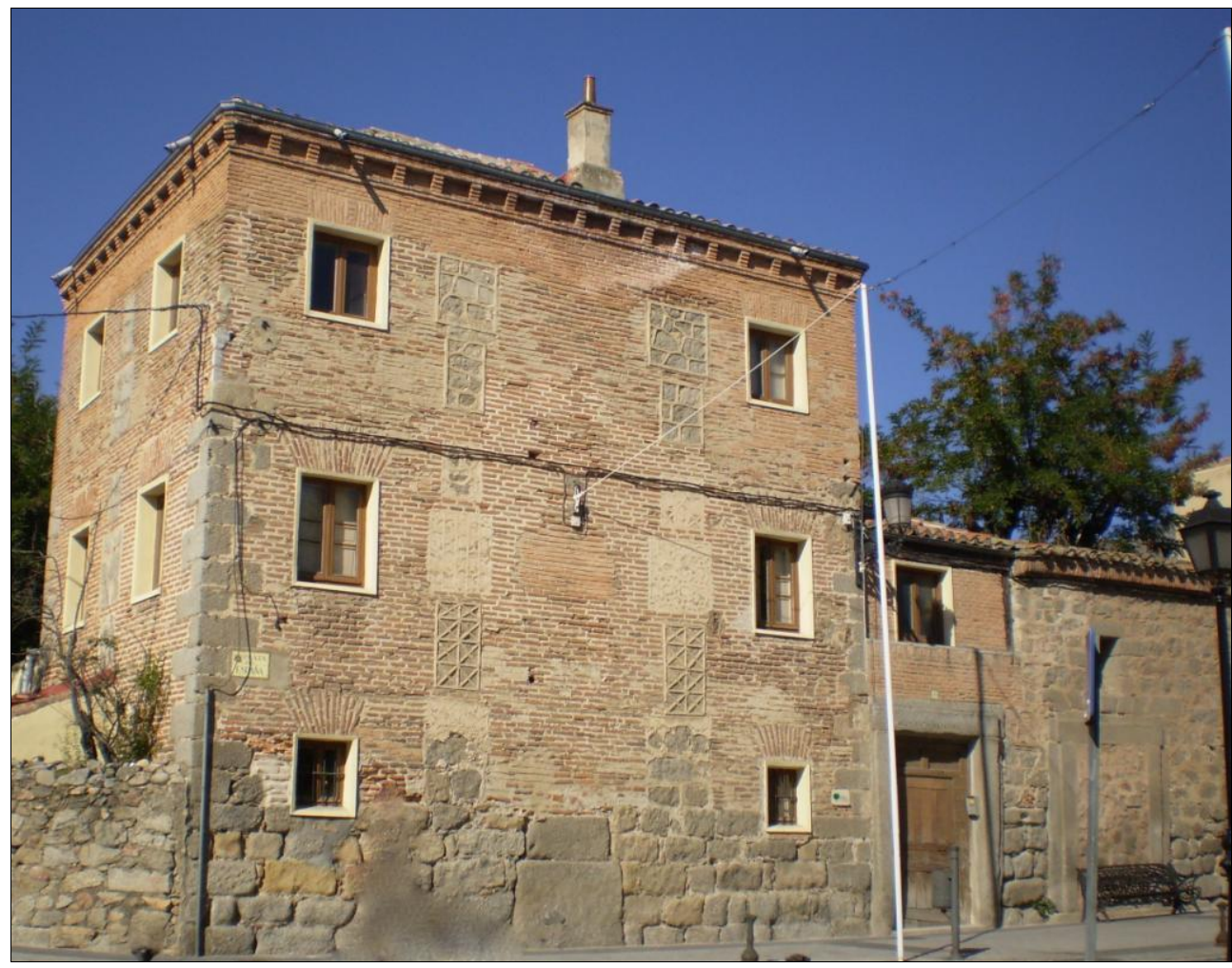

- Fig. 2. El Monasterio "de Prestado" de la Villa de El Escorial. Aspecto actual del edificio situado en la plaza de España, entre la calle de San Lorenzo y la calle de Alfolí (www.esacademic.com).

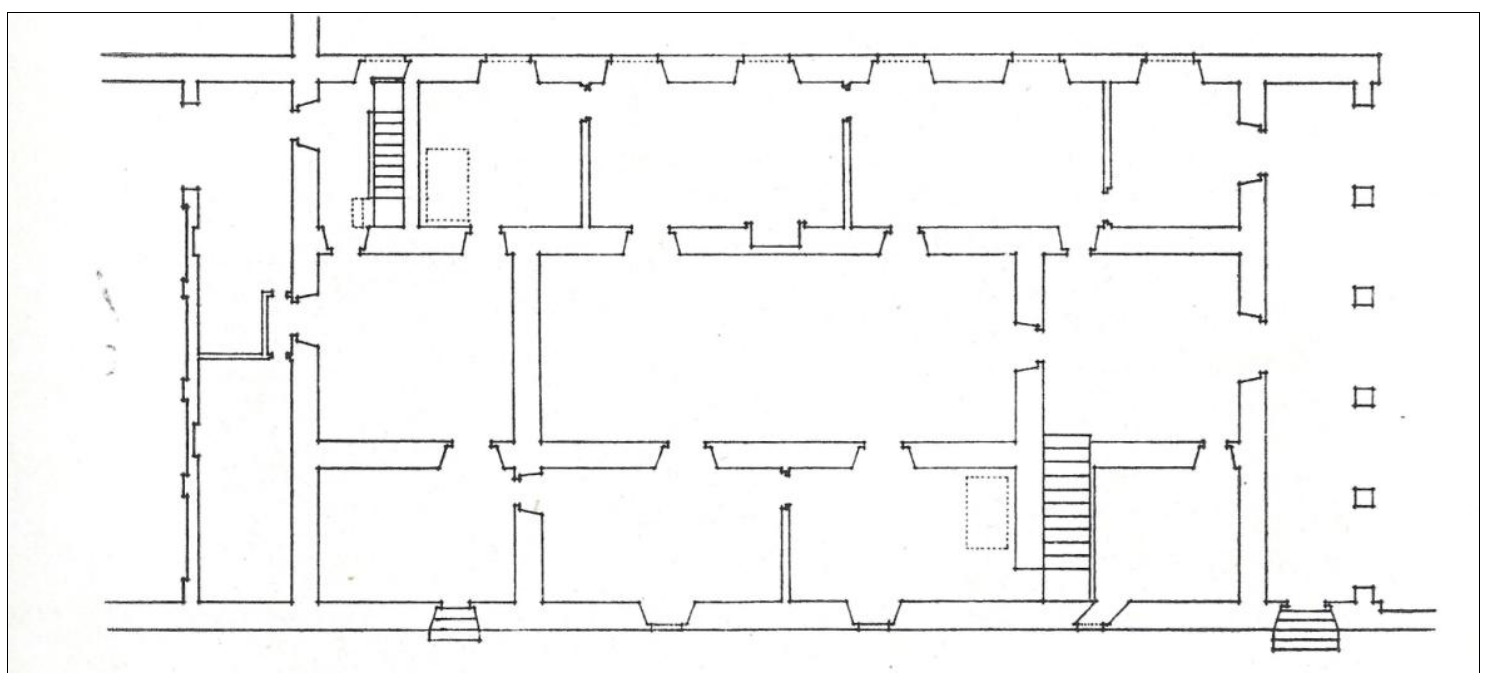

- Fig. 3. El Monasterio "de Prestado" de la Villa de El Escorial: a) Planta de la casa, copia de un original de la época (según P. L. FERNÁNDEZ Y FERNÁNDEZ, «España en tiempos de Felipe II...», pp. 613 y 614. En el texto no se da referencia sobre la procedencia ni la cronología exacta del plano). 


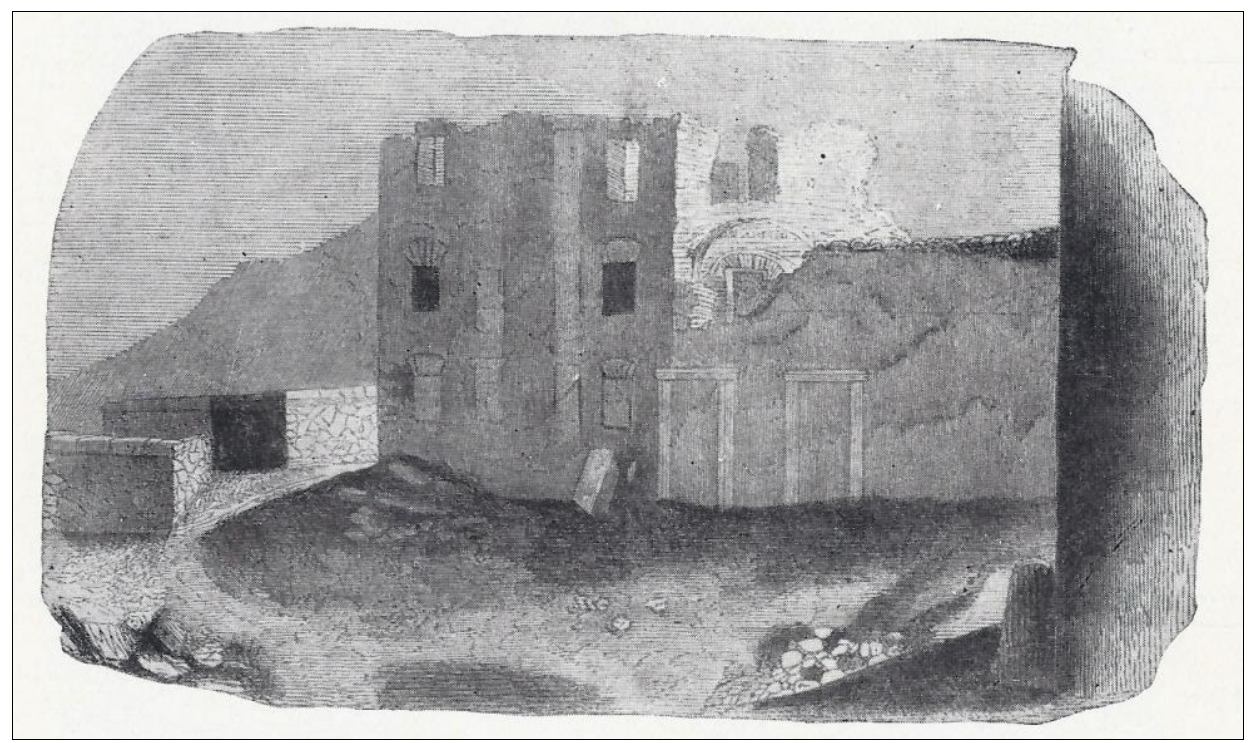

- Fig. 4. El Monasterio "de Prestado" de la Villa de El Escorial: b) Ruinas del convento en un grabado de 1862 (A. ROTONDO, Historia artística..., p. 23.).

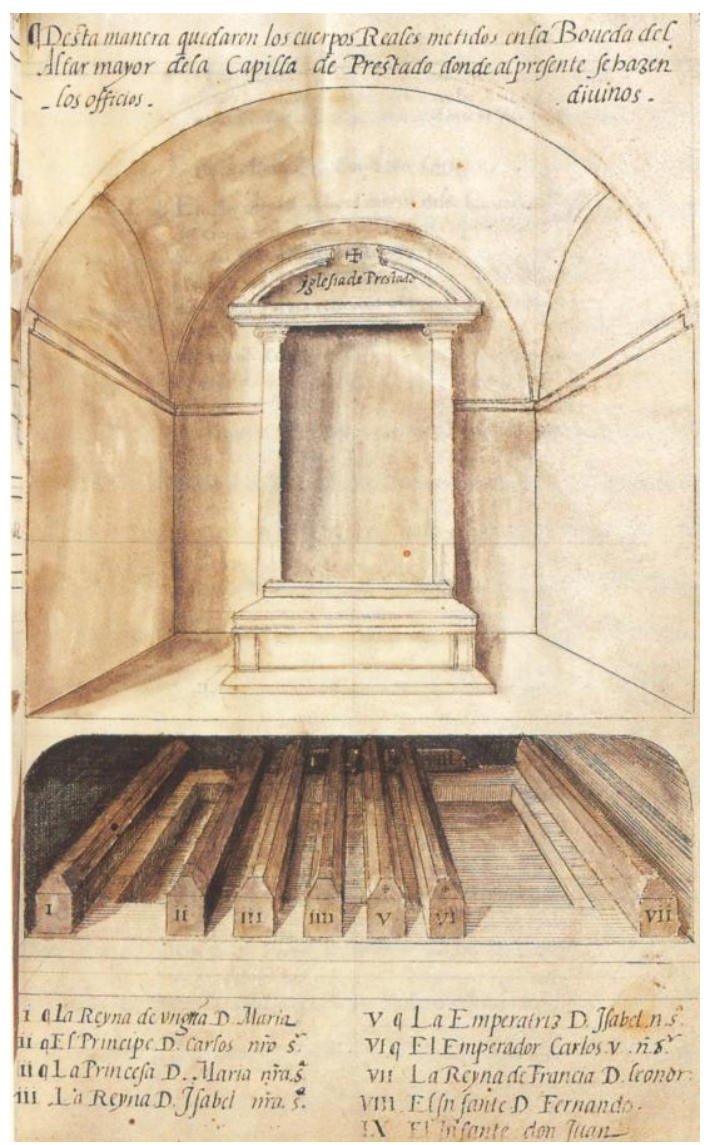

- Fig. 5. Retablo de la Iglesia de Prestado del Real Sitio (Ms. K-I-7, B.M.S.L. A. Bustamante, Trazas..., p. 320.). 


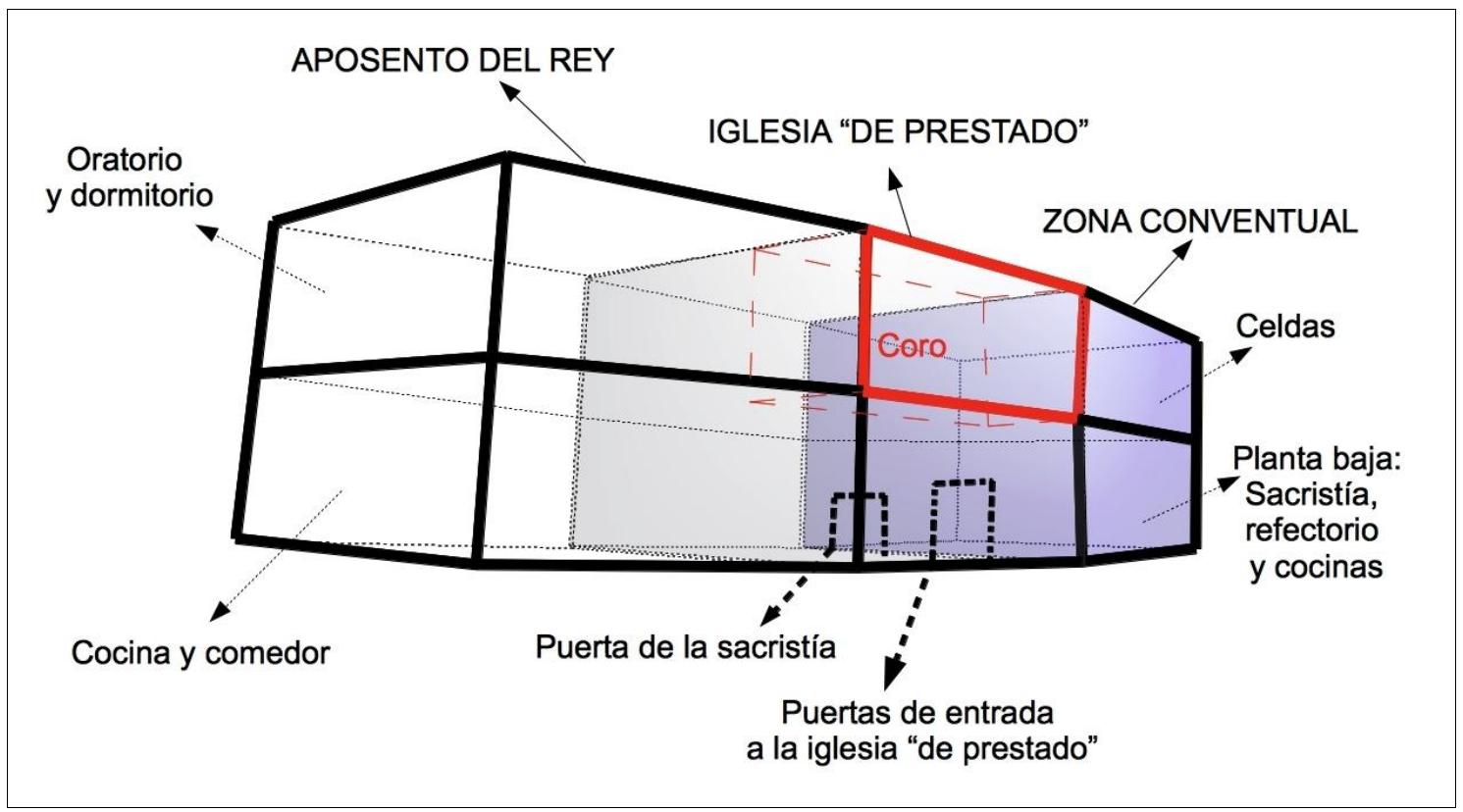

- Fig. 6. Recreación figurada del aspecto del Monasterio "de Prestado" y de su iglesia, según los datos extraídos de la orden de 1566. 